Shantayanan Devarajan

Dani Rodrik

Working Paper No. 3176

NATIONAL BUREAU OF ECONOMIC RESEARCH

1050 Massachusetts Avenue

Cambridge, MA 02138

November 1989

This research was undertaken with financial support from the World Bank through a Robert S. McNamara Fellowship. We thank Jim Tybout and participants at the NBER conference on "Empirical Studies on Strategic Trade Policy" for helpful comments. This paper is part of NBER's research program in International Studies. Any opinions expressed are those of the authors not those of the National Bureau of Economic Research. 
NBER Working Paper \#3176

November 1989

\title{
PRO-COMPETITIVE EFFECTS OF TRADE REFORM: \\ REFORM FROM A CGE MODEL OF CAMEROON
}

\begin{abstract}
How likely is trade liberalization to produce efficiency gains in the presence of imperfect competition, scale economies, and higher-than-average wages in the modern sectors - - all common features of developing economies? These features create a potential conflict to the extent that traditional notions of comparative advantage would lead us to expect that the modern sectors will be squeezed with liberalization. In this paper we investigate the issue by using an applied general equilibrium model calibrated to Cameroonian data. Under perfect competition, the traditional expectations are borne out: manufacturing sectors on the whole contract, and the cash crops sector (mainly coffee and cocoa) is the main beneficiary; the welfare effect is a wash since the beneficial consequence of expanded imports is offset by labor being pulled away from the modern, high-wage sectors. By contrast, under imperfect competition (in the modern sectors only), trade liberalization produces welfare gains of the order of 1 to 2 percent of real income. The key is the pro-competitive effect of liberalization: domestic firms now perceive themselves as facing a higher elasticity of demand, which spurs them to increase production. Therefore, the modern sectors do much better in terms of output than in the perfectly competitive benchmark. The introduction of scale economies amplifies these results. Under reasonable circumstances imperfect competition will make liberalization more desirable, even in the absence of firm entry and exit.
\end{abstract}

Shantayanan Devarajan

John F. Kennedy School of

Government

Harvard University

Cambridge, MA 02138
Dani Rodrik

John F. Kennedy School of

Government

Harvard University

Cambridge, MA 02138 
I. INTRODUCTION AND OVERVIEW

Disillusioned with the import-substitution policies of the past, an increasing number of developing countries are experimenting with trade liberalization. Concurrently, the present decade is witnessing an explosion of research on trade policy in imperfectly competitive environments. While much of this work is theoretical and partial equilibrium in nature, and inspired by the problems of industrial countries, 1 it has greatly enhanced our ability to analyze trade policies in the presence of market imperfections of the type commonly encountered in the developing world. Indeed, market structures in developing countries exhibit just those features that have been the focus of the new academic literature: oligopolistic competition, entry and exit barriers, and unexploited scale economies. ${ }^{2}$

Nevertheless, trade reform in these countries continues to be evaluated within the perfectly-competitive paradigm, with its robust case for liberalization. When oligopoly and returns to scale are mentioned, it is invariably to add a predictable sweeterer regarding the pro-competitive and rationalization benefits of liberalization. Little serious analysis has been done to check whether these effects will work in the desired direction in the specific circumstances of developing countries. ${ }^{3}$

This paper develops a general-equilibrium model incorporating imperfect

1 For a recent theoretical exposition see Helpman and Krugman (1989). Empirical studies based on this literature are surveyed in Richardson (1989).

2 See Rodrik (1988) for an overview.

3 For some suggestive evidence in the Chilean case, see Tybout, de Melo and Corbo (1989) and de Melo and Urata (1986). 
competition and increasing returns to scale, and applies it numerically to Cameroon to investigate the welfare and resource-allocation consequences of trade liberalization. ${ }^{4}$ The model is in the tradition of applied general equilibrium models pioneered by Harris (1984), which pay special attention to details of market structure, firm entry and exit, and scale effects. It builds on an earlier version of the Cameroon model developed by Benjamin and Devarajan (1985)..$^{5}$

The model contains eleven sectors, six of which are treated as imperfectly competitive (all five manufacturing sectors plus one of the services, construction). We take capital as well as all categories of labor to be mobile across sectors; observed sectoral discrepancies in returns to capital in the oligopolistic sectors are attributed to excess profits. Imports and domestically produced goods are imperfect substitutes in demand. This means domestic firms retain some market power, even though - as a small country - Cameroon has no control over world prices. The level of excess profits, together with demand-side parameters, help us calibrate the number of firms for each imperfectly-competitive sector in the base equilibrium, assuming Cournot-Nash behavior. Increasing returns to scale, in turn, are modeled by attributing some of firms' labor and capital payments to a fixed cost component which is independent of the scale of production.

our conclusions regarding the effects of trade liberalization can be summarized as follows. In all of our experiments with an (1989).

4 Some of our results were reported earlier in Devarajan and Rodrik

5 See also Condon, Dahl, and Devarajan (1986). 
imperfectly-competitive market structure, we find that the manufacturing sector as a whole expands, to the detriment of agriculture in general and the cash crops sector in particular. This stands in sharp contrast with what may have been expected in a country at Cameroon's level of development, as well as with the results of the model in the presence of perfect competition. Moreover, these results are insensitive to the ease with which firms can enter and exit industries. The number of firms that move tends to be small when such movement is allowed. Turning to welfare effects, these are positive but not overwhelming, amounting to around 2 percent of GNP. In the absence of economies of scale, these effects are considerably smaller. Significantly, we find evidence that the presence of imperfect competition enhances the benefits of trade liberalization. Once again, firm entry and exit play only a small role: allowing free entry and exit enhances the welfare benefits of liberalization, but not greatly so.

The behavior of the manufacturing sectors is the key determinant of these results, as it is in these sectors that we face potential conflicts in policy objectives. To see this, consider the consequences of a small perturbation in an economy characterized by a number of important distortions: imperfect competition, increasing returns to scale, wage differentials in favor of modern industries, and, not the least, trade protection. The real-income effect of such a perturbation can be decomposed in the following manner (see Rodrik 1988):

(I.1) $d y=\Sigma\left(P_{i}-P_{i}^{*}\right) d M_{i}+\Sigma\left(P_{i}-A C_{i}\right) d X_{i}+$

$$
\Sigma n_{i} A C_{i}\left[1-\left(1 / s_{i}\right)\right] d x_{i}+\Sigma\left(w_{i}-\bar{w}\right) d L_{i} \text {, }
$$


where $i$ indexes sectors, $p$ and $p^{*}$ are the domestic and world prices, $M, X$ and $L$ are the quantities of net imports, output and employment, $A C$ is the average cost, $n$ the number of firms, $s$ the ratio of average to marginal costs, $x$ the output of the representative firm in a given sector, $w_{1}$ and $\bar{w}$ the sectoral and economy-wide average wages. Each one of the terms on the right-hand side picks up the effects of a distinct distortion. As shown by the first term, in an otherwise undistorted economy, trade reform would be welfare increasing by spurring imports in sectors where domestic prices are kept above world prices. In standard models with perfect competition, this would have the implication that the domestic manufacturing sectors would contract along their supply curves as domestic prices of imports and importsubstitutes fall.

But the second and third terms in the equation suggest that this may be a mixed blessing: As the repository of excess profits and unexploited scale economies (second and third terms, respectively), these manufacturing sectors are already operating at too small a scale from the perspective of these two features. Since excess profits and scale economies imply that prices exceed average costs, which in turn exceed marginal costs, it is desirable for manufacturing to expand on account of these imperfections. This conflict is at the heart of the fundamental indeterminacy regarding the welfare benefits of trade liberalization in the presence of imperfect competition. It creates the possibility that liberalization will deteriorate welfare by squeezing those manufacturing firms that are already operating at sub-optimal capacity. In our model, this conflict is aggravated by the presence of an important labor-market distortion (picked up by the last term in the equation): as is common in developing countries, 
wage levels for similar types of labor are generally higher in the manufacturing sectors than in the rest of the economy. This creates an additional reason why manufacturing output is sub-optimal.

The Harris (1984) model mentioned above demonstrates an attractive way out of this dilemma. Assume that firms can freely enter and exit industries, as profitability conditions change. Then trade liberalization will reduce the number of firms in the protected manufacturing sectors that come under pressure, helping the remaining firms achieve greater scale economies. ${ }^{6}$ The rationalization of industry in this fashion renders compatible the goals of higher imports and expanded domestic production lines. In fact, the productivity improvements that come about as the remaining firms travel down their average cost curves can be large enough to stimulate the growth of the manufacturing sector as a whole, greatly amplifying the efficiency benefits of liberalization. While Harris' study was on Canada, a recent paper by Gunasekera and Tyers (1989) obtains a similar outcome in an advanced developing country, South Korea.

Imperfect competition does not stand in the way of welfare gains in our model either. But the mechanism at work is different from that considered by Harris, since free entry and exit do not materially affect our results. Instead, we find that liberalization has an output-expanding, pro-competitive effect in key manufacturing industries: as import competition stiffens, domestic firms' market power erodes, stimulating them to expand production. In more technical terms, the (perceived) marginal revenue curve faced by domestic firms becomes flatter, thereby diminishing

6In terms of equation (I.1), note that the second and third terms can be combined to read $\Sigma\left(\mathrm{p}_{i}-M C_{i}\right) \mathrm{dx}_{i}+\Sigma A C_{i} \mathrm{x}_{i}\left[\left(1 / \mathrm{s}_{\mathrm{i}}\right)-1\right] \mathrm{d} n_{i}$. For some qualifications on rationalization, see Brown and Stern (1989). 
the previous incentive to withhold sales to prop up prices. In many manufacturing sectors, this effect outweighs the greater market share now enjoyed by imports (i.e., the inward shift in the demand curve faced by firms) and leads to an expansion of output. This pro-competitive effect operates even in the absence of entry and exit, which explains the relatively small role played by firm mobility in our model compared to Harris (1984) and other models in the same spirit.

While the pro-competitive effect is recognized in policy discussions, ours is the only applied general-equilibrium study in which it emerges as the centerpiece. Our results provide some justification for remaining sanguine about the effects of trade liberalization in the imperfectly competitive environments characterizing developing countries. Since the industry rationalization effect relies on firm mobility it could be shortcircuited in many developing economies where weak financial markets create frictions in entry and exit. The pro-competitive effect therefore represents an important channel through which trade liberalization can become compatible with desirable expansion in the manufacturing sector even in the absence of industry rationalization.

II. THE CAMEROONIAN ECONOMY, DATA AND MODEL SPECIFICATION

After a brief description of the structure of the Cameroonian economy, this section documents the calibration procedure used and the adjustments made to the computable general equilibrium (CGE) model of Cameroon to incorporate imperfect competition and scale economies. A complete statement 
of the model is given in the Appendix.

\section{A. The Cameroonian Economy}

This paper is based on data from the Republic of Cameroon in 1980. One of the wealthier countries in Sub-Saharan Africa (its per capita income in 1986 was $\$ 900$ ), Cameroon represents an ideal case for a prototypical study like ours. Like most developing countries at its stage in development, Cameroon is primarily an agricultural economy with over 70 percent of the population employed in agriculture. In 1980, this sector also provided the lion's share of foreign exchange to the economy, mainly from exports of cash crops - coffee and cocoa (Table II.1). The industrial sector, which has grown rapidly since independence (albeit from a tiny base), processes Cameroon's natural resources and produces some light consumer goods. This sector has enjoyed protection from import competition. The pattern of protection is reflective of most developing countries: high tariffs on food processing and consumer goods and lower ones on intermediate and capital goods (Table II.1). Furthermore, imports and domestically-produced goods in the same sector are not perfect substitutes in demand. The elasticity of substitution between the two is higher for consumer goods and processed foods, and lower for producer goods. Finally, there is evidence that the Industrial sector, unlike the agricultural sector, is characterized by imperfect competition and economies of scale. The resource-based industries require high fixed investments in plant and equipment. Consequently, some of the sub-sectors consist of only a few firms. Cameroon's industrial policy in the 1960s, based on building large, state-owned enterprises, also 
led to an imperfectly-competitive market structure in many industries.

Table II. 1

The Came roontan economy, 1979-80.

\begin{tabular}{|c|c|c|c|c|c|}
\hline Sectors & $\begin{array}{l}1979-80 \text { Net } \\
\text { trade }{ }^{a} \\
\text { (billions } \\
\text { of CFA } \\
\text { Francs) }\end{array}$ & $\begin{array}{l}\text { Export/ } \\
\text { production } \\
\text { ratio ( } 8)\end{array}$ & $\begin{array}{l}\text { Imports/ } \\
\text { domes- } \\
\text { tically } \\
\text { produced } \\
\text { supply } \\
\text { ratio ( })\end{array}$ & $\begin{array}{l}\text { Elasticity } \\
\text { of sub- } \\
\text { stitution } \\
\text { between } \\
\text { imports and } \\
\text { domestic } \\
\text { goodsb }\end{array}$ & $\begin{array}{l}\text { Tariff } \\
\text { rate }(z) c\end{array}$ \\
\hline 1. Food crops & 2.133 & 1.39 & 0 & 1.5 & 22.1 \\
\hline 2. Cash crops & 117.026 & 95.14 & 10.0 & 0.9 & 23.3 \\
\hline 3. Forestry & 22.314 & 75.71 & 0 & 0.4 & 27.8 \\
\hline 4. Food processing & 5.49 & 32.56 & 24.9 & 1.25 & 35.3 \\
\hline 5. Consumer goods & -31.198 & 4.95 & 31.3 & 1.25 & 38.3 \\
\hline 6. Intermediate goods & -37.241 & 35.63 & 48.7 & 0.5 & 17.7 \\
\hline 7. Cement \& base metals & -39.115 & 30.73 & 145.2 & 0.5 & 26.3 \\
\hline 8. Capital goods & -130.881 & 37.27 & $1,308.0$ & 0.75 & 26.8 \\
\hline 9. Construction & 0 & 0.00 & - & - & - \\
\hline 10. Private services & 7.187 & 13.26 & 12.1 & 0.4 & 0 \\
\hline 11. Public services & 0.00 & 0.00 & - & - & - \\
\hline
\end{tabular}

Notes: a. $\$ 1-210$ CFA Francs.

b. Assumed values.

c. Effective tariff rate, calculated as the ratio of tariff revenues to import values.

This textbook-like pattern of development was severely jolted in the 1980's when Cameroon became an oil exporter. The impact of oil revenues on the real exchange rate and competitiveness of the traditional tradable sectors (the "Dutch disease") has prompted the government to reconsider its development strategy. ${ }^{7}$ Particularly since 1986 , as oil prices and

7 For a discussion of the impact of oil revenues on the Cameroonian economy, see Benjamin et al. (1987). 
Cameroon's reserves have declined, the issue of alternative sources of foreign exchange has become important. On the agenda for the post-oil era is trade liberalization, as part of a more "outward-oriented" development strategy. Hence, the question we ask in this paper, "what are the consequences of trade liberalization for an economy that exhibits the characteristics of Cameroon?" Is of interest to the country 1tself.

\section{B. Calibration Procedure}

Despite the anecdotal evidence, hard data on market structure and the degree of economies of scale in Cameroon are hard to come by. Yet, this information is necessary if we are to simulate the effects of trade liberalization in the presence of these factors in Cameroon. We now describe the calibration procedure used to derive the benchmark equilibrium given the data that we do have on Cameroon.

For the six oligopolistic sectors, we observe ${ }^{8}$ capital and labor inputs in physical terms, their prices, and, in values, interindustry purchases, domestic sales and export sales. We then make the following simplifying as sumptions :

1. All production functions are Cobb-Douglas in labor and capital inputs and Leontief (fixed coefficients) in intermediate inputs.

2. Capital earns a uniform rate of return in the benchmark year of five percent. In the oligopolistic sectors, any excess of revenues over wage,

8 The details of how these were derived are given in Benjamin and Devarajan (1983). 
capital and intermediate costs is treated as excess profits; in the other sectors, the excess is attributed to a sector-specific factor of production

3. The representative household in the economy has a Cobb-Douglas utility function (giving rise to a linear demand system) over composite goods, which in turn are a CES aggregate defined over imported and domestically-produced commodities. Domestically produced goods within a composite good are taken to be perfect substitutes for each other. ${ }^{9}$ This gives rise to a market demand elasticity for the domestic good that is calculated as:

$$
\text { (II.1) } \epsilon=-\left\{\sigma+(1-\sigma) \frac{\delta^{-\sigma}\left(\mathrm{P}^{\mathrm{d}}\right)^{1-\sigma}}{(1-\delta)^{-\sigma}\left(\mathrm{P}^{\mathrm{m}}\right)^{\mathrm{I- \sigma}}+\delta^{-\sigma}\left(\mathrm{P}^{\mathrm{d}}\right)^{\mathrm{I- \sigma}}}\right)
$$

where $\sigma$ is the elasticity of substitution between imports and domestically produced substitutes (Armington elasticity), and $\mathrm{P}^{\mathrm{d}}$ and $\mathrm{P}^{\mathrm{m}}$ are the prices of domestic goods and imports, respectively. 10 The demand elasticity is calculated as the percentage change in domestic demand for the domestic good in response to a unit percentage increase in $\mathrm{P}^{\mathrm{d}}$, while holding all domestic expenditures on the relevant composite commodity (i.e., the CES aggregate) fixed.

Inspection of equation (II.1) shows that $\epsilon$ increases in absolute value whenever the relative price of imports $\left(\mathrm{P}^{\mathrm{m}} / \mathrm{P}^{\mathrm{d}}\right)$ falls. This plays an important role in the analysis, as it implies that domestic firms will behave more competitively as a consequence of trade liberalization. While the relationship between the demand elasticity and the relative price of

9 This differs from Harris (1984) and other models in the same spirit where domestic firms are assumed to be producing imperfect substitutes.

10 The values for $\sigma$ are given in Table II.1. 
imports is a direct consequence of our CES demand system, we believe it captures an important feature of reality, especially in the presence of quantitative restrictions.

5. The oligopolistic firms behave in a Cournot-Nash fashion. Under this hypothesis, the firms' perceived demand elasticity for domestic sales is $N \varepsilon$, where $\mathrm{N}$ is the number of firms in that sector. 11 For export sales, the demand elasticity in each sector is set equal to -20 , reflecting Cameroon's minuscule market power in world markets.

Armed with these assumptions, the data described above, and normalizing the prices of imports and domestic goods at unity, we solve the following system of simultaneous equations for each oligopolistic sector.

(II. 2) $\quad \mathrm{MC}=(1 / \mathrm{A}) \operatorname{m}_{\mathrm{m}-1}^{3}\left(\mathrm{w}_{\mathrm{m}} / \boldsymbol{a}_{\mathrm{m}}\right)^{\alpha_{\mathrm{m}}} \cdot\left(\mathrm{rP}^{\mathrm{k}} / \alpha_{\mathrm{k}}\right)^{\alpha_{\mathrm{k}}}+\sum_{\mathrm{j}} \mathrm{INT}_{\mathrm{j}} /(\mathrm{N} \cdot \mathrm{X})$

(II. 3) $\quad \sum W_{m} I_{T a}+r P^{k_{K}}-N \cdot M C \cdot X-\sum I N T_{j}$

(II. 4) $\frac{\mathrm{P}^{\mathrm{d}}\left(1-t^{\mathrm{d}}\right)-\mathrm{MC}}{\mathrm{p}^{\mathrm{d}}\left(1-t^{\mathrm{d}}\right)}=\frac{-1}{\mathrm{~N} \cdot \epsilon}$

(II.5) $\frac{\mathrm{P}^{\mathrm{e}}\left(1-t^{\mathrm{d}}\right)-M C}{\mathrm{P}^{\mathrm{e}}\left(1-t^{\mathrm{d}}\right)}=\frac{-1}{\mathrm{~N} \cdot \eta}$

(II.6) $\quad \mathrm{P}^{\mathrm{e} \cdot \mathrm{E} \cdot \mathrm{N}}=\mathrm{ESALES}$

(II.7) $\quad P^{\mathrm{d}} \cdot \mathrm{D} \cdot \mathrm{N}=$ DSALES

11 In Harris-type models, it is customary to treat the firms' perceived demand elasticity as a constant in the short-run solution. As equation (II.1) makes clear, in our case this elasticity varies with changes in the relative price of imports. 
(II.8) $\quad X=D+E$

where

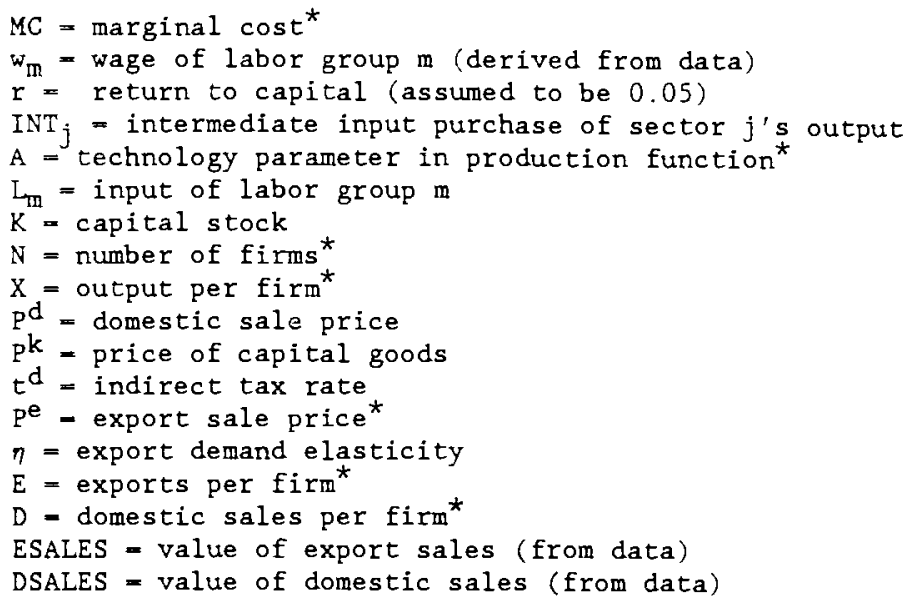

(* Denotes the seven endogenous variables in this calibration exercise.)

The solution gives us, inter alia, the base year values of output, domestic sales, exports, number of firms and excess profits that are consistent with the assumptions and observed data for Cameroon in 1980. The number of firms is an important figure because it is held fixed in the experiments where we assume no entry or exit. As we assume Cournot behavior, we should think of it as the Cournot-equivalent number of firms, rather than the actual number. Similarly, in some simulations allowing for free entry and exit, the level of excess profits is held fixed at its benchmark value. Table II.2(a) shows the calibrated values for the relevant variables. 
Table II. 2

Calibration Results

(a) Constant Returns to Scale ( $s=1)$

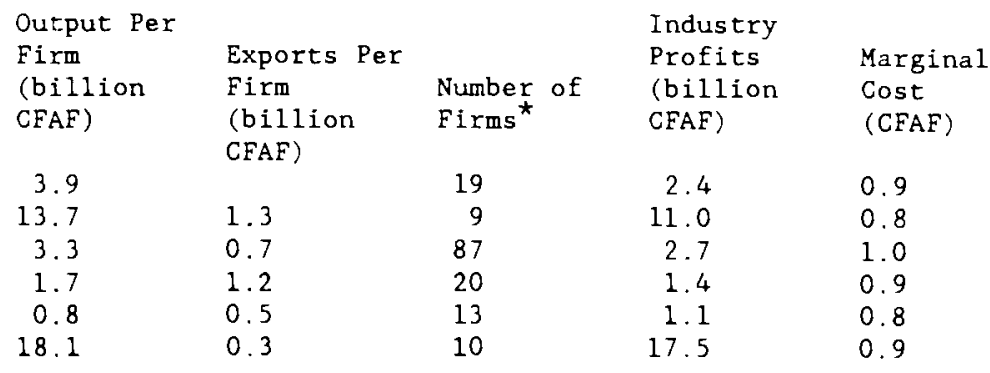

(b) Increasing Returns to Scale $(s=1.25)$

$\begin{array}{lcccc}\begin{array}{l}\text { Output per } \\ \text { Firm }\end{array} & \begin{array}{l}\text { Exports Per } \\ \text { Firm }\end{array} & \begin{array}{l}\text { Number of } \\ \text { Firms }\end{array} & \begin{array}{l}\text { Industry } \\ \text { Profits }\end{array} & \begin{array}{l}\text { Margina1 } \\ \text { Cost }\end{array} \\ 29.1 & 12.0 & 3 & 2.4 & 0.6 \\ 38.0 & 2.6 & 3 & 11.0 & 0.6 \\ 81.6 & 36.2 & 4 & 2.7 & 0.7 \\ 10.8 & 4.3 & 4 & 1.4 & 0.7 \\ 2.6 & 1.3 & 5 & 1.1 & 0.5 \\ 49.3 & - & 4 & 17.5 & 0.7\end{array}$

*rounded to a whole number

Up to now, we have been considering a production technology that exhibits constant returns to scale. To incorporate increasing returns to scale, we assume these stem from a fixed cost component to the cost function. Thus, the total cost (TC) is now made up of a fixed cost (FC) and a marginal cost component that does not depend on the level of firm output:

$\mathrm{TC}=\mathrm{FC}+\mathrm{MC} \cdot \mathrm{X}$ 
The fixed cost is made up of labor and capital costs in the same proportion as in total value added. To calibrate the level of these fixed inputs (and hence the degree of increasing returns), we assume an initial level of the scale parameter $s$, the ratio of average to marginal cost:

$\mathbf{s}=\mathrm{AC}(\mathrm{X}) / \mathrm{MC}$.

Given s, the fixed costs (and the implied fixed labor and capital inputs) can be calculated from:

$$
F C=M C(s-1) X
$$

The scale parameter $s$ is fixed only in the calibration. It varies across simulations, as firm output, factor costs and input prices change. Table II.2(b) shows the callbration results for the same variables as in Table II.2(a), assuming $s=1.25$ across all oligopolistic sectors. Note that the number of firms is much smaller in this calibration. This is because marginal cost is lower in the presence of fixed costs. This higher pricecost margin implies a more collusive industry, i.e., one with fewer firms.

\section{Model Specification}

The calibration equations (II.2) - (II.8) form part of the model that is used to analyze the impact of trade liberalization. The rest of the model, including the behavior of the competitive sectors, is a fairly standard CGE 
model. The equations are given in the Appendix. Here, we describe its salient features:

1. Differentiation between imports and domestic goods by sector: As mentioned earlier, consumers have CES utility functions over imports and domestically produced goods in the same sector. Thus, oligopolistic domestic producers enjoy a certain amolnt of market power, although Cameroon is a price-taker in the world market for competitive imports in those industries.

2. Differentiation between Cameroonlan exports and other exports: We assume Cameroon faces a constant elasticity demand function for its exports However, since we set the demand elasticity at -20 , this is extremely close to the "small country" assumption in exports.

3. Profit maximization by individual producers: For the competitive sectors, this implies setting the wage equal to the value of the marginal product of each of the three labor groups and for capital, with price taken as given. In the oligopolistic sectors, the analogues are equations for the price-cost margin (II.4) and for marginal cost (II.2). The perceived demand elasticity used to calculate the price-cost margin for each firm is endogenous and depends, inter alia, on relative prices in that sector (see equation (II.1)). Thus, each firm's conjectured price-cost margin in equation (II.4) is consistent with the actual margin that obtains in equilibrium. The production functions are all Cobb-Douglas. In the case of economies of scale, the production function is altered to incorporate fixed inputs of labor and capital. If the original production function was $f(K, L)$, it is row $g\left(K-K^{*}, L_{-}-L^{*}\right)$, where $K^{*}$ and $L^{*}$ are the fixed amounts of labor and capital required to start production. The cost of these fixed 
inputs is the fixed-cost component of the total cost.

4. Utility maximization by consumers: The single representative household in this economy maximizes a nested utility function. At the top level, it is a Cobb-Douglas utility function (implying constant expenditure shares) over "composite goods". These composite goods are then divided between imports and domestic goods according to a CES utility function.

5. Market-clearing: There is fuli employment of the three categories of labor (rural, urban-unskilled and urban-skilled) and of mobile capital. Demand and supply of domestic goods in each sector are equilibrated.

6. Labor Markets: There are three labor markets, one for each category of labor. In any given category, labor is mobile across all sectors and the wage for that category clears the labor market. However, workers in the same category do not earn the same wage in each sector. In the benchmark data, the wage bill divided by employment reveals that the wage is not equal across sectors (for the same category). We attribute the difference between these wage payments to sector-specific characteristics, but assume they are a fixed fraction of the (endogenous) wage in that category. Thus, the actual payment to workers in skill category m by sector $i$ is $\mathrm{W}-\mathrm{w}_{\mathrm{m}} \cdot \mathrm{WDIST}_{\mathrm{m}} \mathrm{i}$ where $W_{m}$ is the endogenous wage and WDIST $_{m i}$ is the coefficient representing sector-specific characteristics. Table II. 3 shows the values of WDIST mi in the model. Note that the values are higher for the industrial sectors and lowest for the cash crops sector. Th1s will play a role in interpreting the simulation results of Section III. Naturally, differential wage paid to workers in the same labor market represents a distortion. A policy change that shifts workers from low- to high-paying sectors will thererore improve welfare. Note also that we will keep these premia constant across 
experiments; there are many reasonr to expect that their levels would be affected by trade reform.

\section{Table II. 3: Sectoral Premia on Wages}

$\begin{array}{cc}\text { Rural } & \text { Urban } \\ \text { Unskilled } & \text { Skilled }\end{array}$

$\begin{array}{lrrr}\text { Food Crops } & 1.02 & .71 & \\ \text { Cash Crops } & .50 & .34 & .29 \\ \text { Forestry } & 3.26 & 2.29 & 1.92 \\ \text { Food Processing } & 1.46 & 1.02 & .86 \\ \text { Consumer Goods } & 1.13 & .80 & .67 \\ \text { Intermediate Goods } & 3.11 & 2.18 & 1.83 \\ \text { Cement \& Base Metals } & 6.32 & 4.44 & 3.73 \\ \text { Capital Goods } & 2.50 & 1.76 & 1.48 \\ \text { Construction } & 2.92 & 2.05 & 1.72 \\ \text { Private Services } & 1.40 & .99 & .83 \\ \text { Public Services } & 1.33 & 1.11 & \end{array}$

7. Government: Government earns revenue from trade and indirect taxes, buys a fixed amount (in real terms) of goods as current expenditure, and contributes the difference to a common pool of investible resources. One of the sources of government revenue is a lump-sum tax on households, set initially at zero, which is used to make up the revenue lost from trade liberalization. In this way, the revenue effects of trade liberalization do not affect the welfare calculations reported below.

8. Savings-Investment: In addition to government savings, households save a fixed fraction of their disposable income and the current account deficit is financed by foreign savings (assumed fixed in dollars). The total is equated to the level of investment, which is also fixed in real terms by sector (to avoid the intrusion of intertemporal considerations into our welfare analysis.)

9. Closure rule: From the above, the closure rule is one where the economy's total saving and investment are kept fixed at their initial 
levels, by appropriate adjustments in the lump-sum tax.

10. Numeraire: The numeraire is the nominal exchange rate, or equivalently, the (exogenous) world price of imports.

\section{POLICY EXPERIMENTS}

We now discuss the results of a series of experiments with trade liberalization. Unless otherwise specified, all liberalization experiments involve the elimination of import tariffs across the board. To build intuition about the way the model works, we will proceed in stages. First we discuss the results when all sectors operate under constant returns to scale and there is no firm entry and exit. To see the difference made by imperfect competition, these results are compared with those of an alternative experiment in which all firms are assumed to act competitively. We then move to the case where the imperfectly competitive sectors are also subject to increasing returns to scale (while the number of firms remains fixed). Next, we allow firms to enter and exit in response to changes in sectoral profitability. We end by commenting briefly on the income distributional effects of liberalization under imperfect competition.

\section{A. Constant returns to scale}

The results of trade liberalization in the absence of increasing returns to scale are summarized in Table III.1. The first part of the table 
(A) shows the outcome when "excess profits" are treated as rents accruing to sector-specific factors of production and the firms in each sector are assumed to behave competitively. This establishes a benchmark for comparing the results in the second part of the table, where oligopolistic competition is allowed along the lines sketched earlier.

Liberalization greatly spurs imports in both experiments. As a result, consumer and producer prices are reduced in all of the manufacturing sectors. Notice, however, that trade liberalization has practically no effect on aggregate welfare in the competitive case. This is a consequence of the pre-existing distortions listed in section II above. In particular, liberalization aggravates the welfare costs of wage differentials by pulling labor away from high wage sectors. 12 The net welfare effect is a wash. Under imperfect competition, by contrast, welfare is increased by 1.1 percent. The welfare consequences under the two scenarios cannot be directly compared since the assumption of additional sector-specific factors of production in the first scenario renders the production structure more rigid and reduces the potential gains from trade. But that is only part of the story behind the difference in welfare effects.

The other part is that resource-allocation patterns greatly differ in the two experiments. In the competitive benchmark the main beneficiary of trade liberalization is the cash crops sector, whose output increases by 14 percent. The manufacturing sector as a whole loses out, with relatively large production cuts in consumer goods, cement and base metals, and capital goods. This picture is consistent with the expected pattern of comparative

12 The evidence from this statement comes from an experiment in which wage differentials are assumed away. Trade liberalization then increases welfare by 0.6 percent in the competitive case. 
advantage for a country at Cameroon's level of development. However, when we allow imperfect competition, the manufacturing sector ends up as the beneficiary of liberalization. The cash crops sector now contracts by 5 percent, while the output of food processing, intermediate goods, and especially cement and base metals industries receives a sizable boost. The declines in the two contracting manufacturing sectors (consumer goods and capital goods) are small and less pronounced than before.

The expansion of the manufacturing sector goes hand in hand with a squeeze on excess profits. As Table III.I shows, the aggregate levels of excess profits decline in all but the intermediate goods sector. The latter is spared because it is the least protected sector by the pre-existing tariff structure (see Table II.2), and prima facie the most favored one by liberalization. Even in this case, the proportional increase in profits falls far short of that in output, so that profits normalized by the output level are now lower. The gap between producer prices and marginal costs is therefore reduced in all of the five manufacturing sectors.

The profit squeeze in the manufacturing sector is a natural and expected consequence of intensified import competition. But how can we explain the simultaneous expansion of manufacturing? Under perfect competition, trade liberalization would be expected to reduce domestic production in the most heavily protected sectors (as well it does). Under imperfect competition this conclusion is not foreordained since domestic firms do not have a well-defined supply curve along which they respond to market price. In fact, to the extent that liberalization flattens the marginal revenue curve faced by domestic firms, it spurs production. This can be appropriately termed the "pro-competitive" effect of trade 
liberalization, as it pushes domestic firms to behave in a more competitive manner-i.e., to close the gap between price and marginal cost and expand output.

To see what is going on here it is useful to spend a moment on the implications of liberalization for the first-order condition of the typical, imperfectly competitive firm. To keep the explanation as transparent as possible, let us abstract from interactions among the domestic oligopolists, and concentrate on a single import-competing monopolist at home. Prior to liberalization, the firm's first-order condition is glven by:

(III.1) $\left(\mathrm{PO}_{0}-\mathrm{c}\right)+\mathrm{q}_{0} \mathrm{PO}^{\prime}-0$, where the subscript 0 refers to the base values of price and quantity, and $\mathrm{PO}^{\prime}(<0)$ stands for the derivative of the inverse demand curve evaluated at the initial level of production. For simplicity, marginal costs (c) are taken to be constant. After liberalization, we have the analogous expression:

(III.2) $\left(\mathrm{p}_{1}-\mathrm{c}\right)+\mathrm{q}_{1} \mathrm{p}_{1}^{\prime}=0$

Subtracting the first of these equations from the second and adding and subtracting $\mathrm{q}_{0} \mathrm{P}_{1}^{\prime}$, we get:

(III.3) $\left(p_{0}-p_{1}\right)=q_{0}\left(p_{1}^{\prime}-p_{0}^{\prime}\right)+p_{1}^{\prime}\left(q_{1}-q_{0}\right)$.

Consider the consequences of a reduction in the monopolist's price, as 
would happen when tariff liberalization shifts the monopolist's demand curve inward. Equation (III.3) expresses the necessary correlates of such a price reduction. Since the left-hand side is negative under this scenario, the right-hand side must be negative also. Now when the slope of the demand curve remains unchanged in the new equilibrium, the output consequence can be read off easily: $\left(p_{1}{ }^{\prime}-p_{0}{ }^{\prime}\right)=0$, implying $\left(q_{1}-q_{0}\right)<0$ ( since $\left.p_{1}{ }^{\prime}<0\right)$. That is, the monopolist will respond to the inward shift in demand by reducing output whenever the shift does not affect the slope of the demand curve. But intensified import competition can have a second effect on the domestic firm's demand curve beyond shifting it inward: it can change its slope and make it flatter. This is what happens in our model as import liberalization renders the demand faced by domestic firms more elastic. In terms of the equations above, this corresponds to a reduction (in absolute value) in the magnitude of the derivative of the inverse demand curve, i.e., $\left(p_{1}^{\prime}-p_{0}^{\prime}\right)>0$. It follows that the negative effect on firm output will be alleviated. Moreover, if the change in the slope of the demand curve is large enough, equation (III.3) will require that the domestic firm's output increase (i.e., $\mathrm{q}_{1}-\mathrm{q}_{0}>0$ ). This case is illustrated in Figure 1.

This is what is at work in the results reported above. While the demand curve does shift inward, the change in its curvature in the new equilibrium is enough to offset the adverse effect on firms' output.

Domestic firms now perceive themselves as having much less control over their prices, and hence increase production (or contract less than before).

To test the sensitivity of our results to the degree of substitutability between imports and domestic goods, we also ran the model with the Armington elasticity (a) raised to 5.0 in all sectors. The output results of this run 
are reported in Table III.1A. Note that the relationship between $\sigma$ and the change in demand elasticity is ambiguous and complex (as can be seen by examining expression [II.1]). But when imports become closer substitutes for domestic goods, the inward shift in the demand curve facing domestic firms following liberalization is magnified. On this account alone, we would expect the resource pulls to be less favorable to the heavily protected sectors. This is generally borne out in Table III.1A: note in particular that the cash crops sector now expands. Therefore, greater substitutability of imports for domestic goods blunts the output-expanding effect of liberalization in the modern sectors.

\section{B. Increasing returns to scale}

We now turn to the results of the same policy experiment when firms in the imperfectly competitive sectors also operate under increasing returns to scale (IRS). Our approach in calibrating the level of IRS is ad hoc, but necessarily so. Very little solid information exists on the scale characteristics of technology in countries like Cameroon, so we are forced to take a short cut. As explained above, we first break total primary-factor costs into two components, fixed and variable costs. The latter are assumed to be linear in the level of production, while the former are independent of scale of the operation, which gives us decreasing average costs. We attribute 20 percent of total costs in the base calibration to fixed costs, which appears to be a reasonable benchmark from which to assess the impact of IRS. This yields a scale parameter $s$ (the ratio of average to marginal cost) of 1.25 in the initial equilibrium. Note 
that $s$ will change as a consequence of any shock to the economic system, to the extent that relative prices and firms' scale of output are affected. We expect the gains from trade liberalization to be magnified to the extent that firms travel down their average cost curves, i.e., $s$ is reduced.

The results of trade liberalization under IRS are displayed in Table III.2. In terms of resource pulls, the main difference with the earlier experiment is the much greater responsiveness of the expanding manufacturing sectors: food products expand by 26 percent (earlier 12 percent), intermediate goods by 21 percent (earlier 13 percent), and cement and base metals by 109 percent (earlier 45 percent). This magnification comes from the reduction in unit costs (or alternatively, increase in factor productivity) as the scale of output is expanded. This is borne out by the reduction in $s$ in each of these three sectors. Note also that the contraction of the food crops sector is now reversed, while the cash crops receives an even greater squeeze. In fact, the latter sector is the predominant source of the resources released to manufacturing. From the perspective of the traditional tenets of comparative advantage, this is a rather unusual outcome.

The introduction of IRS also magnifies the consequences for the level of excess profits. Four of the imperfectly competitive sectors (food processing, consumer goods, capital goods, and construction) now suffer a reduction in the aggregate level of excess profits of the order of 10-30 percent. Meanwhile the cement and base metals sector receives a large boost.

Wj.th the introduction of IRS, the positive welfare effect of liberalization is almost doubled, rising from 1.1 percent (of base welfare) 




Figure 1 
to 2.0 percent. This is in large part due to the beneficial scale effects of liberalization. There are relatively large reductions in unexploited scale economies in the food products, intermediate goods, and cement and base metals sectors, as captured by the fall in $s$ in these sectors. The increases in $s$ in the other three sectors with IRS are comparatively small. Also, recall from section II that the introduction of a fixed cost drives a greater wedge between prices and marginal costs (so that we can remain consistent with observed data on revenue and total costs). Since the oligopolistic sectors tend to expand, the welfare benefits are therefore magnified.

\section{Increasing Returns to Scale with Free Entry and Exit of Firms}

We now turn to the consequences of allowing the number of firms in each imperfectly competitive sector to adjust freely in response to changes in profitability. The appropriate way to view this scenario is not necessarily as a long-run outcome; after all, we allow full labor and capital mobility in the previous experiments. Instead, we can think of this scenario as a hypothetical one with no rigidities in industrial structure. In line with accepted terminology, however, we will refer to this as the "long-run" scenario. The usual manner in which this scenario is constructed is to fix the level of excess profits in each industry to zero, and to let the number of firms adjust endogenously. In our case, the results of such an experiment would not be directly comparable with our base values since our base calibration allows for excess profits: we would be comparing a long-run 
equilibrium under free trade with a short-run equilibrium under trade protection.

There are two ways in which we can surmount this conceptual difficulty. First, we can establish a new benchmark by solving for an equilibrium in which the existing levels of trade protection are kept fixed, but the number of firms is left free to vary under the zero-profit constraint. We can then compare a zero-profit, free-trade outcome with this benchmark. Second, we can assume that the "observed" pattern of excess profits represents a long-run solution to begin with. Under this scenario, our free entry experiments would fix the level of firm profits not to zero but to the initial level of profits. Table III. 3 presents the results of liberalization experiments under both sets of assumptions. It turns out that the consequences of free entry and exit in the two scenarios are virtually indistinguishable from each other.

Notice first that the number of firms declines in all four sectors which had been subject to a profit squeeze in the earlier experiment. The exit rate, however, is not spectacular: on the order of $2-4.5$ percent. This is comparable to observed entry and exit rates in developing countries, albeit in the absence of policy shocks: for example, Tybout (1989) and Roberts (1988) find net exit rates to average around -3 and 6 percent per year in three-digit industries in Chile and Colombia, respectively. The entry rates in the remaining two sectors are even smaller at around 1-2 percent. 13 These results suggest that in the present model firm-level profits are highly sensitive to changes in competitive pressure brought by

${ }^{13}$ The somewhat higher observed entry/exit rates must also reflect the presence of marginal firms, which is ruled out in our symmetric setup. 
entry and exit of firms.

As entry and exit turns out to be limited, we cannot expect great differences in resource-allocation and welfare effects from the earlier experiment. Indeed, the pattern of sectoral output remains virtually unchanged, and the overall welfare effect of liberalization is only slightly higher at 2.2 percent. We notice from the changes in $s$ that, relative to the earlier experiment, firm mobility has on the whole desirable consequences for scale. But the effects are not large. Hence, our results provide little evidence of drastic industry rationalization of the sort discovered by Harris (1984) and Gunasekera and Tyers (1989).

D. Income Distribution

Another area where we would expect imperfect competition to make a difference is income distritution. The present model has fifteen income groups: nine primary factors (capital, three categories of labor and five sector-specific factors in the competitive sectors) and six groups of oligopolists in the imperfectly competitive industries. Table III.4 displays the changes in rates of remuneration of these groups after trade liberalization, in the absence of entry and exit. Note that these are changes in nominal (i.e. undeflated) incomes. But since we have assumed that all consumers have identical and homothetic preferences, these numbers can be used to ascertain how various income groups do relative to each other. The nominal incomes can be converted to real terms by using the 
change in the consumer price index, reported at the bottom of the table.

All three labor categories are gainers, as is capital. The biggest losers are the specific factor in cash crops and the oligopolists in four of the six imperfectly competitive sectors. One of the other two sets of oligopolists is the biggest gainer, along with the capitalists. What is evident is that the introduction of oligopolistic rents into the analysis renders distributional consequences much more complex. It becomes possible for all primary factors of production to gain from liberalization, at the expense of oligopoly rents. In our analysis, only two out of nine primary factors turn out to be losers, but both of these are in agriculture (food and cash crops). That the distributional consequences of liberalization can be adverse to agricultural groups is once again in conflict with conventional wisdom.

IV. CONCLUSIONS

Given the myriad assumptions we have made to calibrate and run our model, it would be foolhardy to draw direct policy conclusions from the above for Cameroon, let alone for developing countries in general. But our exercise nonetheless provides some interesting conclusions about what might be expected from a more open trade regime in an imperfectly competitive developing economy.

In particular, our results suggest that pro-competitive forces operating on oligopolistic firms will play an important role in countries 
undergoing trade liberalization. Such forces affect the resource pulls in the economy, thereby influencing the magnitude of the efficiency gains from liberalization. Even when the desirability of liberalization remains unaffected, these differences in resource pulls are interesting in their own right. As our results show, intuition based on perfect competition and traditional tenets of comparative advantage can prove very misleading with respect to the 1 ikely consequences of liberalization. Unlike in the perfectly competitive version of our model, liberalization draws resources away from cash crops and into manufacturing. Agricultural landlords are among the biggest losers. To developing-country policy makers with a penchant for industrialization, then, trade liberalization should look a lot. more appealing in the presence of imperfect competition. Provided, that is, they can withstand the political consequences of the loss of oligopoly rents in manufacturing. 
Table III.1: Results with Constant Returns to Scale

\section{(A) PERFECT COMPETITION}

\begin{tabular}{|c|c|c|c|c|c|c|c|c|}
\hline \multirow[b]{2}{*}{ Sector } & \multicolumn{2}{|c|}{ output } & \multicolumn{2}{|c|}{$\begin{array}{l}\text { imports } \\
\text { (volume) }\end{array}$} & \multicolumn{2}{|c|}{$\begin{array}{l}\text { exports } \\
\text { (volume) }\end{array}$} & \multicolumn{2}{|c|}{ profits } \\
\hline & $\begin{array}{l}\text { base } \\
\text { level }\end{array}$ & $\begin{array}{l}\text { percent } \\
\text { change }\end{array}$ & $\begin{array}{l}\text { base } \\
\text { level }\end{array}$ & $\begin{array}{l}\text { percent } \\
\text { change }\end{array}$ & $\begin{array}{l}\text { base } \\
\text { level }\end{array}$ & $\begin{array}{l}\text { percent } \\
\text { change }\end{array}$ & $\begin{array}{l}\text { base } \\
\text { level }\end{array}$ & $\begin{array}{l}\text { percent } \\
\text { change }\end{array}$ \\
\hline Food crops & 330.5 & -3.2 & 2.5 & 28.0 & 4.6 & -1.3 & -- & $\cdots$ \\
\hline Cash crops & 131.5 & 14.3 & 8.0 & 14.1 & 125.1 & 14.7 & - & $\cdots$ \\
\hline Forestry & 29.5 & 3.6 & $\cdots$ & - & 22.3 & 3.1 & - & $\cdots$ \\
\hline Food proc. & 72.0 & 1.9 & 18.0 & 32.1 & 23.5 & 7.8 & - & -- \\
\hline Cons. goods & 118.4 & -2.6 & 37.1 & 36.9 & 5.9 & 3.1 & - & - \\
\hline Interm. goods & 284.4 & 5.4 & 138.6 & 7.6 & 101.3 & 8.3 & - & - - \\
\hline Cembbase met. & 34.2 & -2.1 & 49.6 & 3.3 & 10.5 & 4.0 & - & - \\
\hline Capital goods & 10.3 & -3.2 & 134.7 & 2.6 & 3.8 & -1.6 & - & -- \\
\hline Construction & 174.1 & -0.8 & -- & -- & -- & -- & $\cdots$ & - \\
\hline Priv, services & 615.8 & -0.9 & 74.4 & -1.2 & 81.6 & -0.7 & -- & -- \\
\hline Pub. services & 164.0 & -0.4 & -- & - - & $\cdots$ & -- & $\cdots$ & - \\
\hline
\end{tabular}

Percentage changes:

\begin{tabular}{lccrc} 
& $\begin{array}{c}\text { Percentage changes: } \\
\text { consumer } \\
\text { prices }\end{array}$ & $\begin{array}{c}\text { producer } \\
\text { prices }\end{array}$ & $\begin{array}{c}\text { prices } \\
\text { of VA }\end{array}$ & $\begin{array}{c}\text { marginal } \\
\text { costs }\end{array}$ \\
\hline Food crops & -1.4 & -1.3 & -1.1 & -1.3 \\
Cash crops & -15.3 & -1.1 & 3.5 & -1.1 \\
Forestry & 4.7 & 1.0 & 3.0 & 1.0 \\
Food proc. & -12.7 & -4.7 & -0.0 & -4.7 \\
Cons, goods & -11.2 & -4.6 & -2.1 & -4.6 \\
Interm. goods & -11.4 & -5.6 & -0.5 & -5.6 \\
Cem\&base met. & -17.9 & -8.0 & -0.8 & -8.0 \\
Capital goods & -20.5 & -4.0 & -0.8 & -6.0 \\
Construction & -6.5 & -6.5 & -1.2 & -0.6 \\
Priv. services & -0.6 & -0.6 & -0.2 & -1.1 \\
Pub. services & -1.1 & -1.1 & 0.4 &
\end{tabular}

Increase in welfare $(\%): 0.0 \quad(0.049)$

(cont. on next page) 


\section{(B) IMPERFECT COMPETITION}

\begin{tabular}{|c|c|c|c|c|c|c|c|}
\hline & output & $1 \mathrm{mt}$ & $\begin{array}{l}\text { orts } \\
\text { lume) }\end{array}$ & $\begin{array}{l}\operatorname{expo} \\
(\mathrm{vol}\end{array}$ & $\begin{array}{l}\text { its } \\
\text { ume) }\end{array}$ & prof & its \\
\hline & $\begin{array}{l}\text { base percent } \\
\text { level change }\end{array}$ & $\begin{array}{l}\text { base } \\
\text { leve1 }\end{array}$ & $\begin{array}{r}\text { percent } \\
\text { change }\end{array}$ & $\begin{array}{l}\text { base } \\
\text { leve } 1\end{array}$ & $\begin{array}{r}\text { percent } \\
\text { change }\end{array}$ & $\begin{array}{l}\text { base } \\
\text { leve1 }\end{array}$ & $\begin{array}{r}\text { percent } \\
\text { change }\end{array}$ \\
\hline
\end{tabular}

\begin{tabular}{|c|c|c|c|c|c|c|c|c|}
\hline Food erops & 330.5 & -0.6 & 2.5 & 35.8 & 4.6 & -1.7 & -- & -- \\
\hline Cash crops & 131.5 & -4.5 & 8.0 & 13.2 & 125.1 & -4.4 & - & 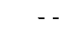 \\
\hline Forestry & 29.5 & 4.6 & -- & - & 22.3 & 2.2 & & \\
\hline Food proc. & 73.1 & 11.9 & 18.0 & 40.6 & 24.6 & 38.6 & 2.4 & -2.6 \\
\hline Cons. goods & 119.1 & -2.2 & 37.1 & 44.4 & 6.5 & 11.3 & 11.0 & -3.7 \\
\hline Interm. goods & 285.9 & 12.7 & 138.6 & $\$ 1.9$ & 102.7 & 28.4 & 2.7 & 1.9 \\
\hline Cemábase met. & 34.8 & 45.1 & 49.6 & 15.0 & 11.1 & 141.7 & 1.4 & -2 \\
\hline Capital goods & 11.1 & -0.4 & 134.7 & 3.9 & 4.6 & 6.5 & 1.1 & -6 \\
\hline Construction & 176.8 & 0.0 & - & $\cdots$ & - & $\cdots$ & 17.5 & -3.2 \\
\hline Priv, services & 615.8 & -1.2 & 74.4 & 0.6 & 74.4 & -2.6 & -- & $\cdots$ \\
\hline Pub. services & 164.0 & -0.3 & $-\cdot$ & -- & $\cdots$ & -- & -- & 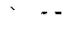 \\
\hline
\end{tabular}

Percentage changes:

$\begin{array}{cccc}\text { consumer } & \text { producer } & \text { prices } & \text { marginal } \\ \text { prices } & \text { prices } & \text { of VA } & \text { costs }\end{array}$

\begin{tabular}{lrrrr}
\hline Food crops & 0.7 & 0.9 & 1.0 & 0.9 \\
Cash crops & -11.4 & 0.1 & 1.0 & 0.2 \\
Forestry & 23.9 & 6.0 & 8.5 & 6.0 \\
Food proc. & -9.1 & -2.0 & 4.7 & -1.6 \\
Cons. goods & -8.3 & -0.7 & 3.3 & -0.5 \\
Interm. goods & -7.3 & -1.3 & 4.8 & -1.2 \\
Cem\&base met. & -15.8 & -5.5 & 4.6 & -4.3 \\
Capital goods & -20.2 & -0.9 & 4.0 & -0.3 \\
Construction & -3.2 & -3.2 & 3.7 & -3.2 \\
Priv. services & 3.7 & 3.7 & 4.2 & 3.7 \\
Pub. services & 3.5 & 3.5 & 5.2 & 3.5
\end{tabular}

Increase in welfare $\left(\frac{8}{)}\right): 1.1$ 
Table III.1A: Output Results under Imperfect Competition and Constant Returns to Scale with Armington Elasticity $(\sigma)$ Raised to 5.0 for All Tradable Sectors

Percent Change in Output:

$\begin{array}{lrlr}\text { Food Crops } & -2.0 & \text { Intermediate goods } & 20.0 \\ \text { Cash Crops } & 3.7 & \text { Cem \& base metals } & 57.8 \\ \text { Forestry } & 8.0 & \text { Capital goods } & -8.2 \\ \text { Food Processing } & 15.7 & \text { Construction } & 0.7 \\ \text { Consumer Goods } & -23.6 & \text { Public services } & -0.1\end{array}$


Table III.2: Results with Increasing Returns to Scale

\begin{tabular}{|c|c|c|c|c|c|c|c|c|}
\hline \multirow[b]{2}{*}{ Sector } & \multicolumn{2}{|c|}{ output } & \multicolumn{2}{|c|}{$\begin{array}{l}\text { imports } \\
\text { (volume) }\end{array}$} & \multicolumn{2}{|c|}{$\begin{array}{l}\text { exports } \\
\text { (volume) }\end{array}$} & \multicolumn{2}{|c|}{ profits } \\
\hline & $\begin{array}{l}\text { base } \\
\text { leve } 1\end{array}$ & $\begin{array}{r}\text { percent } \\
\text { change }\end{array}$ & $\begin{array}{l}\text { base } \\
\text { level }\end{array}$ & $\begin{array}{r}\text { percent } \\
\text { change }\end{array}$ & $\begin{array}{l}\text { base } \\
\text { leve } 1\end{array}$ & $\begin{array}{c}\text { percent } \\
\text { change }\end{array}$ & $\begin{array}{l}\text { base } \\
\text { leve } 1\end{array}$ & $\begin{array}{r}\text { percent } \\
\text { change }\end{array}$ \\
\hline Food crops & 330.5 & 0.8 & 2.5 & 41.1 & 4.6 & -2.6 & - & - \\
\hline Cash crops & 131.5 & -11.1 & 8.0 & 15.8 & 125.1 & -11.3 & $\cdots$ & -- \\
\hline Forestry & 29.5 & 8.3 & $\ldots$ & - & 22.3 & 4.2 & -- & -- \\
\hline Food proc. & 82.9 & 25.8 & 18.0 & 44.4 & 34.3 & 59.2 & 2.4 & -28.6 \\
\hline Cons. goods & 120.8 & -0.9 & 37.1 & 47.7 & 8.2 & 2.2 & 11.0 & -13.2 \\
\hline Interm. goods & 329.3 & 21.0 & 138.6 & 16.4 & 146.3 & 36.7 & 2.7 & -0.5 \\
\hline Cembbase met. & 39.1 & 109.1 & 49.6 & 27.3 & 15.5 & 257.2 & 1.4 & 22.9 \\
\hline Capital goods & 13.4 & -0.9 & 134.7 & 5.1 & 6.9 & 2.1 & 1.1 & -24.2 \\
\hline Construction & 174.1 & 1.6 & $\cdots$ & -- & -- & - & 17.5 & -15.9 \\
\hline Priv. services & 615.8 & -0.4 & 74.4 & 2.9 & 74.4 & -2.8 & -- & - \\
\hline Pub. services & 164.0 & 0.0 & -- & -- & $\cdots$ & -- & $\cdots$ & $\cdots$ \\
\hline
\end{tabular}

percentage changes:

\begin{tabular}{ccccc}
$\begin{array}{l}\text { consumer } \\
\text { prices }\end{array}$ & $\begin{array}{l}\text { percentage changes: } \\
\text { prices }\end{array}$ & $\begin{array}{c}\text { prices } \\
\text { of VA }\end{array}$ & $\begin{array}{c}\text { marginal } \\
\text { costs }\end{array}$ & $\begin{array}{c}\text { change in } \\
\text { s }\end{array}$ \\
\hline 2.3 & 2.5 & 2.6 & 2.54 & -- \\
-9.1 & 0.8 & 0.0 & 0.8 & -- \\
39.7 & 10.1 & 13.5 & 10.1 & -- \\
-9.7 & -6.3 & -14.4 & -2.3 & -0.04 \\
-8.1 & -0.3 & 5.3 & -0.1 & 0.01 \\
-7.8 & -3.9 & -6.1 & -1.6 & -0.03 \\
-16.3 & -15.9 & -24.7 & -6.2 & -0.12 \\
-20.2 & -1.4 & 6.0 & -0.1 & 0.02 \\
-4.3 & -4.3 & 4.2 & -4.3 & 0.02 \\
6.5 & 6.5 & 7.1 & 6.2 & -- \\
5.4 & 5.4 & 7.2 & 5.2 & --
\end{tabular}

Increase in welfare (8): 2.0 
(A) EXCESS PROFITS FIXED AT ZERO

\begin{tabular}{|c|c|c|c|c|c|c|c|c|}
\hline \multirow[b]{2}{*}{ Sector } & \multicolumn{2}{|l|}{ output } & \multicolumn{2}{|c|}{$\begin{array}{l}\text { imports } \\
\text { (volume) }\end{array}$} & \multicolumn{2}{|c|}{$\begin{array}{l}\text { exports } \\
\text { (volume) }\end{array}$} & \multicolumn{2}{|c|}{ \# of firms } \\
\hline & $\begin{array}{l}\text { base } \\
\text { leve1 }\end{array}$ & $\begin{array}{r}\text { percent } \\
\text { change }\end{array}$ & $\begin{array}{l}\text { base } \\
\text { level }\end{array}$ & $\begin{array}{c}\text { percent } \\
\text { change }\end{array}$ & $\begin{array}{l}\text { base } \\
\text { level }\end{array}$ & $\begin{array}{c}\text { percent } \\
\text { change }\end{array}$ & $\begin{array}{l}\text { base } \\
\text { level }\end{array}$ & $\begin{array}{r}\text { percent } \\
\text { change }\end{array}$ \\
\hline Food crops & 330.5 & 1.0 & 2.5 & 41.9 & 4.6 & -2.7 & -- & - \\
\hline Cash crops & 131.5 & -10.9 & 8.0 & 15.9 & 125.1 & -11.1 & - - & .. \\
\hline Forestry & 29.5 & 8.5 & - - & - - & 22.3 & 4.4 & $\cdots$ & - \\
\hline Food proc. & 89.9 & 23.6 & 18.0 & 45.3 & 34.3 & 74.8 & 3 & -2.1 \\
\hline Cons. goods & 120.8 & -1.7 & 37.1 & 48.5 & 8.2 & -16.3 & 3 & -2.8 \\
\hline Interm. goods & 329.3 & 20.9 & 138.6 & 16.5 & 146.3 & 33.0 & 4 & 0.1 \\
\hline Cem\&base met. & 39.1 & 105.7 & 49.6 & 26.0 & 14.6 & 216.3 & 4 & 1.1 \\
\hline Capital goods & 13.4 & -0.7 & 134.7 & 5.2 & 6.9 & -32.5 & 5 & -4.5 \\
\hline Construction & 174.1 & 1.5 & - - & - - & -- & -- & 4 & -3.1 \\
\hline Priv, services & 615.8 & -0.2 & 74.4 & 3.0 & 74.4 & -2.6 & - & $\cdots$ \\
\hline Pub, services & 164.0 & 0.1 & - & - - & - - & - & - - & $\cdots$ \\
\hline
\end{tabular}

percentage changes

$\begin{array}{ccccc}\text { consumer } & \text { producer } & \text { prices } & \text { marginal } & \text { change in } \\ \text { prices } & \text { prices } & \text { of VA } & \text { costs } & s\end{array}$

\begin{tabular}{lrrrrr}
\hline Food crops & 2.5 & 2.7 & 2.8 & 2.7 & - \\
Cash crops & -9.1 & -1.1 & 0.0 & -1.1 & - \\
Forestry & 38.5 & 8.6 & 13.2 & 8.6 & - \\
Food proc. & -8.8 & -5.0 & -15.0 & -2.0 & -0.04 \\
Cons. goods & -7.3 & 0.7 & 3.6 & -0.1 & 0.01 \\
Interm. goods & -7.8 & -3.9 & -6.7 & -1.5 & -0.03 \\
Cem\&base met. & -16.5 & -15.4 & -25.5 & -6.2 & -0.13 \\
Capical goods & -20.2 & 0.1 & 3.8 & -0.3 & 0.01 \\
Construction & -3.4 & -3.4 & 1.9 & -4.3 & 0.01 \\
Priv. services & 6.5 & 6.4 & 7.1 & 6.4 & -- \\
Pub. services & 5.1 & 5.1 & 6.7 & 5.1 & -
\end{tabular}

Increase in welfare $(8): 2.2$

(cont. on next page) 
(B) EXCESS PROFITS FIXED AT INITIAL LEVEL

\begin{tabular}{|c|c|c|c|c|c|c|c|c|}
\hline \multirow[b]{2}{*}{ Sector } & \multicolumn{2}{|c|}{ output } & \multicolumn{2}{|c|}{$\begin{array}{l}\text { imports } \\
\text { (volune) }\end{array}$} & \multicolumn{2}{|c|}{$\begin{array}{l}\text { exports } \\
\text { (volume) }\end{array}$} & \multicolumn{2}{|c|}{ \# of firms } \\
\hline & $\begin{array}{l}\text { base } \\
\text { level }\end{array}$ & $\begin{array}{r}\text { percent } \\
\text { change }\end{array}$ & $\begin{array}{l}\text { base } \\
\text { leve1 }\end{array}$ & $\begin{array}{l}\text { percent } \\
\text { change }\end{array}$ & $\begin{array}{l}\text { base } \\
\text { level }\end{array}$ & $\begin{array}{r}\text { percent } \\
\text { change }\end{array}$ & $\begin{array}{l}\text { base } \\
\text { leve } 1\end{array}$ & $\begin{array}{l}\text { percent } \\
\text { change }\end{array}$ \\
\hline Food crops & 330.5 & 0.9 & 2.5 & 41.3 & 4.6 & -2.5 & -- & -- \\
\hline Cash crops & 131.5 & -10.9 & 8.0 & 15.5 & 125.1 & -11.1 & -- & $\cdots$ \\
\hline Forestry & 29.5 & 8.5 & -- & -- & 22.3 & 4.3 & -- & $\ldots$ \\
\hline Food proc. & 82.9 & 23.3 & 18.0 & 45.0 & 34.3 & 54.6 & 3 & -2.1 \\
\hline Cons. goods & 120.8 & -2.0 & 37.1 & 48.4 & 8.2 & 1.1 & 3 & -2.6 \\
\hline Interm, goods & 329.3 & 21.2 & 138.6 & 16.8 & 146.3 & 36.7 & 4 & 0.3 \\
\hline Cem\&base met. & 39.1 & 117.2 & 49.6 & 27.5 & 15.5 & 275.6 & 4 & 2.4 \\
\hline Capital goods & 13.4 & 0.4 & 134.7 & 5.3 & 6.9 & 5.5 & 5 & -4.2 \\
\hline Construction & 174.1 & 1.4 & - & - & - - & -- & 4 & -2.9 \\
\hline Priv. services & 615.8 & .0 .2 & 74.4 & 3.0 & 74.4 & -2.7 & -- & - - \\
\hline Pub. services & 164.0 & 0.1 & -- & -- & - & - & -- & -- \\
\hline
\end{tabular}

percentage changes

\begin{tabular}{lllll} 
& \multicolumn{2}{c}{ percentage changes } & \\
\hline consumer & producer & prices & marginal & change in \\
prices & prices & of VA & costs & $\mathrm{s}$
\end{tabular}

\begin{tabular}{|c|c|c|c|c|c|}
\hline Food crops & 2.3 & 2.4 & 2.6 & 2.4 & -- \\
\hline Cash crops & -9.2 & 0.7 & -0.1 & 0.7 & $=-$ \\
\hline Forestry & 39.5 & 10.0 & 13.4 & 10.0 & -- \\
\hline Food proc. & -8.9 & -5.5 & -14.7 & -2.2 & -0.04 \\
\hline Cons. goods & -7.3 & 0.8 & 4.0 & -0.1 & 0.01 \\
\hline Interm. goods & -7.8 & -3.9 & -6.4 & -1.5 & -0.03 \\
\hline Cemabase met. & -16.7 & -16.8 & -25.4 & -6.3 & -0.12 \\
\hline Capital goods & -20.1 & -0.1 & 4.0 & -0.3 & 0.00 \\
\hline Construction & $-3 \cdot 3$ & -3.3 & 2.5 & -4.4 & 0.01 \\
\hline Priv. services & 6.5 & 6.5 & 7.2 & 6.5 & -- \\
\hline Pub. services & 5.2 & 5.2 & 6.9 & 5.2 & - \\
\hline
\end{tabular}

Increase in welfare (8): 2.2 
Table III.4: Distributional Consequences of Trade Liberalization*

(percent changes in remuneration from base levels)

I. Primary Factors:

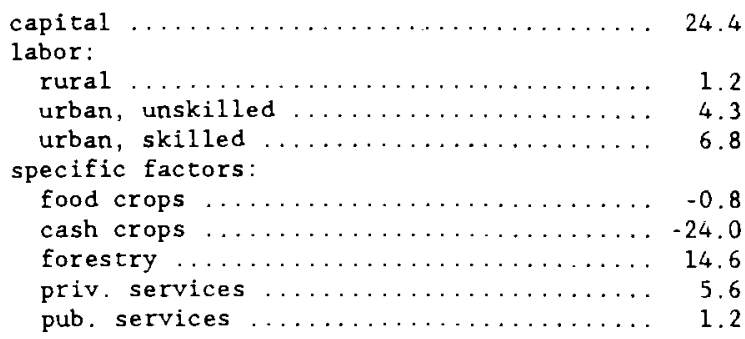

II. 01igopoly profits

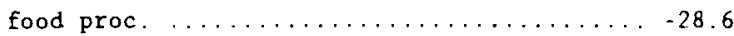

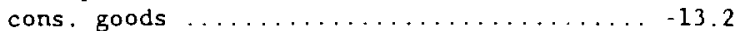

interm. goods ....................

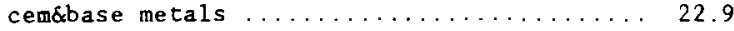

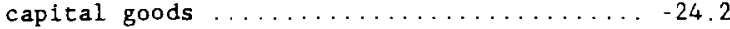

construction ......................

Memo: aggregate consumer

price index ................... -0.3

Note: *The trade liberalization experiment in question is the one with IRS $(s=1.25)$ and no entry and exit. 


\section{REFERENCES}

Benjamin, Nancy, and Shantayanan Devarajan, 1985, "Oil Revenues and Economic Policy in Cameroon: Results from a Computable General Equilibrium Model," World Bank Staff Working Paper.

Benjamin, Nancy; Shantayanan Devarajan and Robert J. Weiner, 1989, "The 'Dutch Disease' in a Developing Country: Oil Revenues in Cameroon," journal of Development Economics, vol 30. pp. 71-92.

Brown, Drusilla K., and Robert M. Stern, 1989, "U.S. - Canada Bilateral Tariff Elimination: The Role of Product Differentiation and Market Structure," in Robert C. Feenstra (ed.), Trade Policies for International Competitiveness, Chicago and London: The University of Chicago Press.

Condon, Timothy, Henrik Dahl, and Shantayanan Devarajan, 1986, "Implementing a Computable General Equilibrium Model on GAMS: The Cameroon Model," unpublirhed paper, April.

Devarajan, Shantayanan, and Dani Rodrik, 1989, "Trade Liberalization in Developing Countries: Do Imperfect Competition and Scale Economies Matter?", American Economic Review, Papers and Proceedings, May.

Gunasekera, Don, and Rod Tyers, 1989, "Imperfect Competition and Returns to Scale in a Newly Industrializing Economy: A General Equilibrium Analysis of Korean Trade Policy," Working Paper 89-4, Department of Economics, The University of Adelaide.

Harris, Richard, 1984, "Applied General Equilibrium Analys is of Small Open Economies with Scale Economies and Imperfect Competition, "American Economic Review 77, pp. 1016-1032.

Helpman, Elhanan, and Paul R. Krugman, 1989, Trade Policy and Market Structure, Cambridge, MA: The MIT Press.

Melo, Jaime de, and S. Urata, 1986, "The Influence of Increased Foreign Competition on Industrial Concentration and Profitability, " International Journal of Industrial Organization.

Richardson, J. David, 1989, "Empirical Research on Trade Liberalization with Imperfect Competition: A Survey," OECD Economic Studies, No. 12.

Roberts, Mark, 1988, "The Structure of Production in Colombian Manufacturing Industries," unpublished paper.

Rodrik, Dani, 1988, "Imperfect Competition, Scale Economies, and Trade Policy in Developing Countries," in Robert E. Baldwin, ed., Trade Policy Issues and Empirical Analysis, Chicago: The University of Chicago Press.

Tybout, James, 1989, "Entry, Exit, Competition, and Productivity in the Chilean Industrial Sector," unpublished paper. 
Tybout, James, Jaime de Melo, and Vittorio Corbo, 1989, "The Effects of Trade Reforms on Scale and Efficiency: New Evidence from Chile," unpublished paper, June. 
Appendix

Equations of the Model

(i) $\mathrm{P}_{i}^{\mathrm{M}}=\mathrm{pw}_{i}^{\mathrm{M}}\left(1+\mathrm{t}_{\mathrm{i}}^{\mathrm{M}}\right) \mathrm{ER}$

(2) $\mathrm{P}_{i}^{E}=P W_{i}^{E} E R$

(3) $P_{1}=\left(P_{i}^{D_{i}} D_{i}+P_{i}^{M} M_{i}\right) / Q_{i}$

(4) $P_{i}^{v}=P_{i}^{D}\left(1-t_{i}^{x}\right)-\sum_{j} P_{j} a_{j i}$

(5) $P_{i}^{X}=\sum_{j} P_{j} b_{j 1}$

(6) $x_{1}-a_{1}^{D} \Pi L_{f 1}^{\alpha_{f 1}}$

(7) $W_{f}$ WDIST $_{E i}=P_{i}^{v} \alpha_{f i} X_{i} / L_{f i}$

(8) $\operatorname{INT}_{i}=\sum_{j} a_{i j} X_{j}$

(9) $E_{i}=$ econst $\left(P W_{i}^{E} / P W S E_{i}\right)^{-\rho_{i}^{E}}$

(10) $Q_{1}=a_{1}^{c}\left[\delta_{1} M_{1}^{-\rho^{0}}+\left(1-\delta_{i}\right) D_{1}^{-\rho_{1}^{c}}-1 / \rho_{1}^{c}\right.$

(11) $M_{i}=D_{i}\left[\left(P_{i}^{D} / P_{1}^{M}\right)\left(\delta_{1} /\left(1-\delta_{i}\right)\right)\right]^{-1 /\left(1+p_{i}^{c}\right)}$

(12) $\mathrm{Y}_{\mathrm{f}}^{F}=\sum_{i} \mathrm{~W}_{f}$ WDIST $_{f i} \mathrm{~L}_{f i}$

(13) $Y^{H}=\sum_{f} Y_{f}^{F}-$ DEPRECIA - TRANSFER $+\sum_{i}$ PROFITS $_{i}$

(14) TARIFF $=\sum_{i} t_{i}^{M} \mathrm{Pw}_{1}^{M} M_{1} \mathrm{ER}$

(15) INDTAX $=\sum_{i} t_{i}^{x} P_{i}^{x} X_{i}$

(16) DEPRECIA $-\sum_{1} \operatorname{depr}_{i} \mathrm{P}_{i} \mathrm{~L}_{11}$

40 
(17) HHSAV $=$ MPSOY ${ }^{H}$

(18) GR - TARIFF + INDTAX + TRANSFER

(19) GOVSAV - GR $-\sum_{i} P_{i} G_{i}$

(20) SAVINGS - HHSAV + GOVSAV + DEPRECIA + FSAVOER

(21) $\mathrm{P}_{i} \mathrm{C}_{i}-\beta_{i}^{G}(1-\mathrm{MPS}) \mathrm{Y}^{\mathrm{B}}$

(22) $\mathrm{G}_{1}=\beta_{i}^{\mathrm{G}} \mathrm{GDTOT}$

(23) $\operatorname{DST}_{i}=\operatorname{dstr}_{i} \mathrm{X}_{i}$

(24) FXDINV - INVEST $-\sum_{i} P_{1}$ DST $_{i}$

(25) $P_{i}^{K} D_{1}=k_{1} \operatorname{shr}_{1} X_{1}$

(26) $I D_{i}-\sum_{j} b_{i j} D_{j}$

(27) $\mathrm{x}_{1}=\mathrm{INT}_{1}+\mathrm{C}_{1}+\mathrm{G}_{i}+\mathrm{ID}_{i}+\mathrm{DST}_{i}$

(28) $\sum_{i} L_{f 1}-\lambda_{f}$

(29) $\sum_{1} P w_{i}^{M} M_{1}=\sum_{i} \mathrm{PW}_{1}^{E_{1}} E_{1}+F S A V$

(30) SAVINGS = INVEST

011gopolistic sectors only

(31) $M C_{1}-f\left(W_{1}, \ldots, W_{m}, r, P_{1}, \ldots, P_{N}\right)$

(32) $P_{1}^{D}\left(1-t_{1}^{x}\right)-M C_{1}$ $\overline{P_{1}^{D}\left(1-t_{1}^{x}\right)}--1 / N_{1} \epsilon_{1}$ 
(33) $\frac{P_{i}^{E}\left(1-t_{1}^{x}\right)-M_{i}}{P_{i}^{E}\left(1-t_{i}^{x}\right)}--1 / N_{i} \eta_{i}$

(34) $\mathrm{AC}_{i}-\mathrm{s}_{i} \mathrm{MC}_{i}$

(35) $X_{i}=g_{i}\left(L_{1}, \ldots, I_{m}, s_{i}\right)$

(36) PROFITS $_{i}=\left\{\left[P_{i}^{D}\left(X_{i}-E_{i}\right)+P_{i}^{E} E_{i}\right]\left(1-t_{i}^{X}\right)-A C_{i}\right] X_{i}$

\section{Definition of variables}

$P_{i}^{M}=$ domestic price of imports in sector $i$

$\mathrm{pw} \mathrm{w}_{i}^{\mathrm{M}}=$ world price of imports in sector $i$

$t_{i}^{M}=$ tariff rate on imports in sector $i$

$E R$ = nominal exchange rate

$P_{1}^{E}$ - domestic price of exports of sector $i$

$P W_{i}^{E}=$ world price of exports of sector $i$

$\mathrm{P}_{i}=$ price of composite good in sector $i$

$P_{i}^{D}=$ price of domestic good in sector $i$

$D_{i}=$ domestic consumption of domestic good $i$

$M_{i}=$ imports of sector $i$

$Q_{1}=$ consumption of composite good $i$

$P_{1}^{V}=$ price of value added in sector $i$

$t_{i}^{x}=$ indirect $\operatorname{tax}$ in sector $i$ 







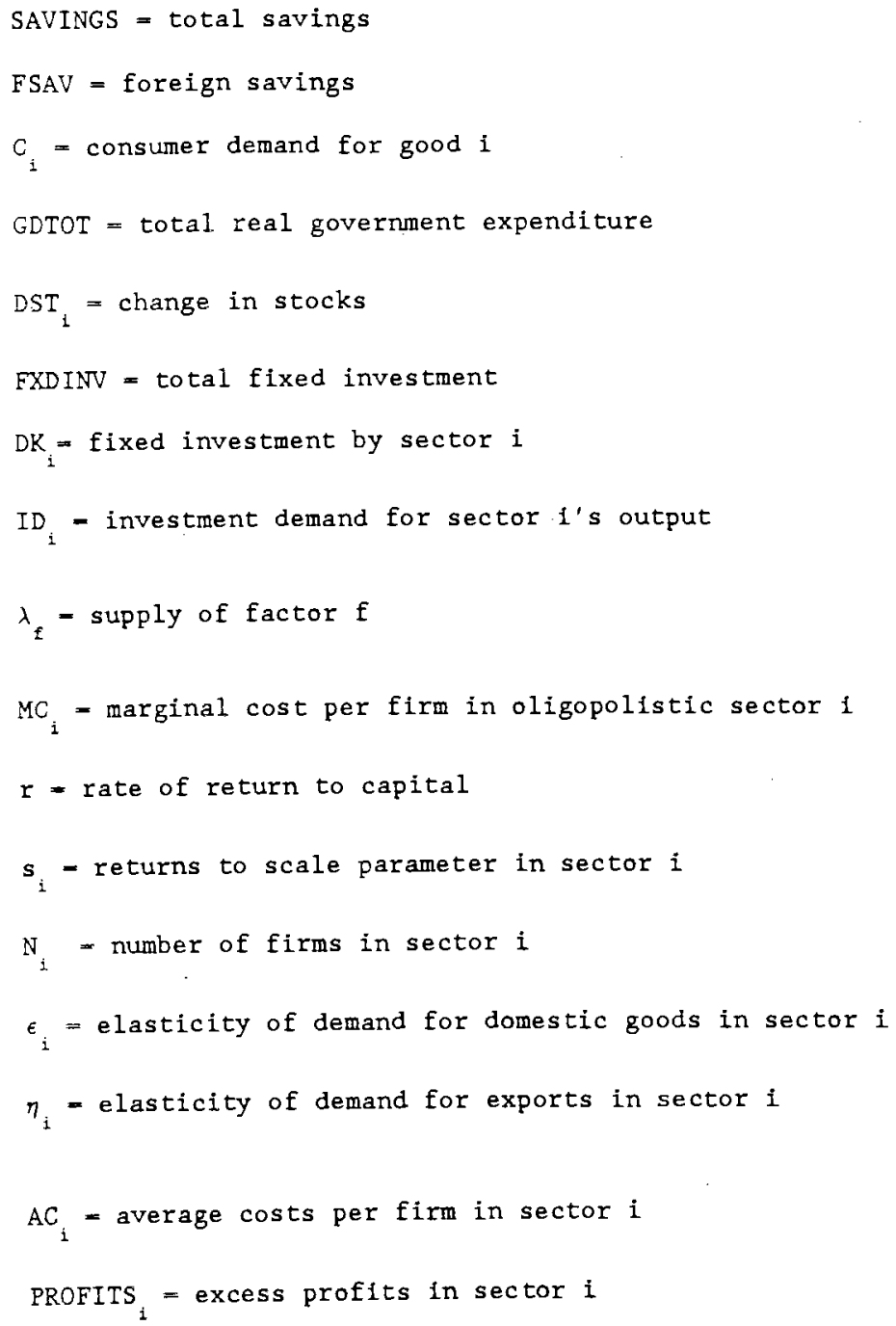

